\title{
FILM CONTENT ANALYSIS AT SIX MAJOR SPANISH FILM LIBRARIES
}

\section{Análisis documental del contenido fílmico en seis filmotecas españolas}

\author{
Rubén Domínguez-Delgado and María-Ángeles López-Hernández
}

Nota: Este artículo se puede leer en español en:

http://www.elprofesionaldelainformacion.com/contenidos/2016/sep/09_esp.pdf

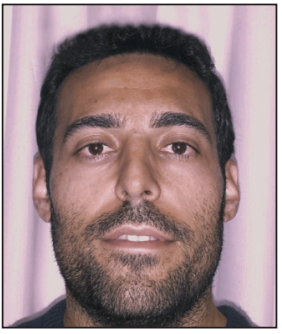

Rubén Domínguez-Delgado holds a bachelor's of audiovisual communication, and bachelor's and doctorate of journalism from the Universidad de Sevilla (University of Seville), where he is a professor in the Department of Journalism I. In Spain he coordinates the Red Iberoamericana de Investigación de la Comunicación (Ibero-American Network of Research on Communication) and his research focuses on the fields of moving image librarianship (mainly on film), news librarianship, and the current problems of journalism, issues about which he has published scientific articles in national and international journals.

http://orcid.org/0000-0001-9885-2831

rdd@us.es

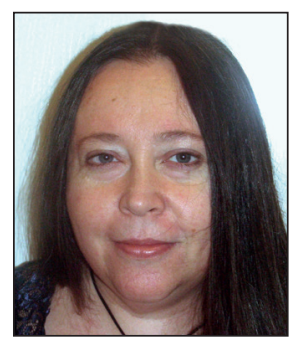

María-Ángeles López-Hernández holds a bachelor's of journalism from the Universidad Complutense de Madrid (Complutense University of Madrid), a doctorate of journalism from the Universidad de Sevilla (University of Seville) where she is currently an associate professor in the Department of Journalism I. She is the general coordinator of the Red Iberoamericana de Investigación de la Comunicación (Ibero-American Network of Research on Communication). Her research activity focuses on the analysis and methodological study of the management of collections in news archives and moving image archives. She is the author of several books about the selection of documents and moving image librarianship, and she has authored scientific articles about the current problems of journalism and their influence on information management.

http://orcid.org/0000-0001-8562-1575

alhernan@us.es

Universidad de Sevilla. Departamento de Periodismo I Av. Américo Vespucio, s/n. 41092 Sevilla, España

\section{Abstract}

In the field of library and information science, content analysis is a fundamental task for the efficient retrieval of information by the users of information systems. In this paper, an analysis is conducted on the current state of this task at six major Spanish film libraries by interviewing those responsible for the content analysis of film collections and performing a comparative analysis of the fields related to film content in the most exhaustive document analysis worksheets employed by each one of these six institutions to catalog their film collections.

\section{Keywords}

Moving image librarianship; Film librarianship; Film libraries; Film archives; Film content analysis; Selective retrieval of moving images.

\section{Resumen}

En el campo de la documentación, una tarea fundamental para una eficaz recuperación de información por parte de los usuarios de los sistemas de información es el análisis de contenido. En la presente investigación analizamos el estado actual de esa tarea en seis importantes filmotecas españolas. Se ha entrevistado a sus responsables de documentación de fondos fílmicos y se ha hecho un análisis comparativo de los campos relativos al contenido fílmico dentro de las fichas de análisis documental aplicadas por cada una de estas seis instituciones sobre sus fondos fílmicos.

\section{Palabras clave}

Documentación audiovisual; Documentación cinematográfica; Filmotecas; Archivos cinematográficos; Análisis documental; Análisis documental de contenido fílmico; Recuperación selectiva de información audiovisual. 
Domínguez-Delgado, Rubén; López-Hernández, María-Ángeles (2016). “Film content analysis at six major Spanish film libraries". El profesional de la información, v. 25, n. 5, pp. 787-794.

https://doi.org/10.3145/epi.2016.sep.09

\section{Introduction}

The crucial importance of performing an adequate film content analysis about efficient searching and retrieval of information that satisfies the information needs of the users is self-evident. In Spain, since the turn of the century, there have been significant advances in this analytic task in the TV branch of film librarianship, with relatively important academic production in this regard (Agirreazaldegi-Berriozabal, 2007; Caldera-Serrano; Sánchez-Jiménez, 2009; RodríguezMateos; Pérez-Lorenzo, 2011), as well as the advent of revolutionary document analysis methodologies as a result of the major transformations that, since 2004, have been brought about by the implementation of new content or media asset management systems (MAM) by the country's main television companies (Agirreazaldegi-Berriozabal, 2007, p. 434). Among other functionalities, these systems envisage the possibility of extracting frames or keyframes from video clips that allow us to visually identify the content of documents without actually executing the videos. The automatic extraction of keyframes is also feasible with programmed time, or even shot change, criteria.

\section{The relative boom in national studies of TV content analysis (and TV librarianship in general) has not been replicated in the field of film librarianship}

Thus, notwithstanding the differences in the databases employed by each Spanish TV archive, we can safely say the selective retrieval of moving images

"has always been one of the ultimate ends pursued by engineers and documentalists who have developed software for moving image archives, shortening response times and making information retrieval more pertinent" (Caldera-Serrano; Sánchez-Jiménez, 2009, p. 299).

Although this brings obvious advantages to users of these information systems, much still needs to be done to improve diverse aspects, including the use of artificial intelligence or cognitive psychology for the further automation of analytic tasks.

We wonder whether or not the concern for document analysis shown by the foremost TV archives in Spain, in accordance with Unesco's 1980 guidelines that state

"access should be made available as far as possible to the works and information sources represented by moving images [...]" (Unesco, 1980),

corresponds to the current reality of the country's other major moving image archives-film libraries.

In the realm of theory, we must briefly note that the relative boom in national studies of TV content analysis (and TV librarianship in general) has not been replicated in the field of film librarianship, which has been conspicuously absent over the last few years. Indeed, in Spain there have been no specific works on film content analysis in moving image archives, beyond the two theoretical proposals put forward by Pinto-Molina, García-Marco and Agustín-Lacruz (2002, pp. 296-309), and López-Hernández (2003, pp. 212-235).

\section{Objectives and methodology}

As a result of this scientific lacuna, the main aim of this case study was to verify, with regard to the professional field of film librarianship (leaving aside theoretical proposals and the recommendations of the International Federation of Film Archives (FIAF) and other international entities), the current state of film content analysis at six major Spanish film libraries. We investigated users' objectives when they visit film archives to search for and retrieve film-related information. We developed two basic methodological lines of research:

1) We conducted a comparative study of the analysis worksheets of six major Spanish film libraries:

- Filmoteca Española http://goo.gl/yrwTiR

- Filmoteca de Andalucía

http://www.filmotecadeandalucia.es

- Filmoteca de Catalunya

http://www.filmoteca.cat

- Filmoteca Vasca

http://www.filmotecavasca.com/es

- Filmoteca de Valencia

http://ivac.gva.es/la-filmoteca

- Centro Galego de Artes da Imaxe (filmoteca gallega). http://www.cgai.org

To this end, we requested the worksheets employed by information specialists at the aforementioned institutions ${ }^{1}$.

Because some film libraries do not use the same analysis worksheet for all their document collections we chose the most comprehensive one for each (viz., the worksheet with the greatest number of fields). This was the case for worksheets from the following collections:

- No-Do Collection of the Spanish Film Library;

- Unicaja Collection of the Andalusian Film Library;

- newscasts and documentaries of the production company Laya Films in the case of the Catalan Film Library;

- films, belonging to different genres without distinction, restored by the Valencia Film Library;

- regional documentaries or newscasts related to Galicia, in the case of the Galician Film Library;

- from the Basque Film Library, which is a special case with 
respect to content analysis, we selected the only analysis worksheet that the institution applies across all of its collections.

However, we should stress that, only when films contain particular clips (be they shots, scenes, or sequences) that are of special interest to Basque Film Library (based on geographical and thematic criteria), its analysts include, solely for the selected clips, information on specific content related to each clip in a different tab in the database record (as will be explained below in more detail).

After obtaining the six analysis worksheets we selected fields related to film content and discarded the formal or external description fields in order to observe whether there was a general concern for film content when designing the worksheets, as well as a consensus or, conversely, a heterogeneity with regard to film content analysis.

Due to the different names that each film library gives to content fields covering the same aspects, we divided the content categories of the worksheets into two large groups. These groups coincided with two major sub-tasks that film content analysis entails, i.e., film content summary and indexing or representation (Pinto-Molina, 1992, p. 89; Fox, 2005 , p. 23), and regarding the latter, we created four broad categories: thematic, onomastic, geographical, and chronological or temporal (Caldera-Serrano; Sánchez-Jiménez, 2009, p. 293).

2) The other basic methodological line of research involved getting into direct contact with the six Spanish film libraries and interviewing those responsible for the content analysis of their film collections. To harmonize the compilation of information from each one of these institutions we developed a standard questionnaire with seven items (see table 1).

Table 1. Standard questionnaire for the information specialists who are responsible for analyzing film collections

Item 1. What is the normal user profile of your film collections?
Item 2. What fields do users usually consult when performing infor-
mation searches?
Item 3. In regards to the analytic process to which film documents
are subjected, do you use an analysis methodology that goes beyond
a mere external description of these documents to address their
content?

Item 4. If so, what type of methodology (shot by shot, sequential, scene by scene, news item by news item in the case of newscasts, etc.), applied to what type of films (regionally produced fiction, regional documentaries, newscasts, etc.), do you employ?

Item 5. Have you ever considered the systematic adoption of an analysis methodology that allows you to search for unusual shots, sequences, or scenes related to a particular content, event, or historical era? Do you believe that it would be interesting and feasible to do this at your film library?

Item 6. Do you have a controlled thesaurus or vocabulary to describe the content of your film collections?

Item 7. What is the most comprehensive cataloging or analysis worksheet that you currently have at your disposal? What fields does it contain and which of these are strictly related to film content?
The idea behind this personal contact was to observe:

- the current structure, organization, problems, and priorities of the six film libraries;

- the tasks carried out by their librarians or information specialists;

- the type of users who request information from these institutions;

- the access and search options open to them in regards to a specific film document, or the treatment to which these documents are subjected, checking above all whether, besides their external or formal description, content analysis methodologies with units of analysis smaller than a film or item, such as sequences, scenes, or shots, are implemented (or whose application has at least been considered).

In short, the aim was to familiarize ourselves with the current work methods of the film libraries under study in order to gain a better understanding of the reasons why they have chosen to apply a particular document analysis methodology.

In the two methodological lines of research developed in this study, the data was gathered during the first half of 2015

The summaries were far from being authentic, comprehensive document summaries that serve as a substitute to viewing the document in question, and thus would be of little real value to users

\section{Results and discussion}

\subsection{Attention paid to film content in the document analysis worksheets of Spanish film libraries}

A comparative study of the content fields of the six worksheets was conducted and the first of the two major tasks involved in film content analysis, summarizing, was included in all of them, although under different names (Table 2). Thus, the field called "synopsis" is the most frequent of all (present in four of the six analysis worksheets), followed by the "summary" field (included in two of the six worksheets), and, lastly, the "storyline" field (only present in the analysis worksheet of the Galician Film Library). It is worth stressing that the worksheet of the Valencia Film Library is the only one that incorporates two different fields related to the task of summarizing: the "synopsis" and "summary" fields. Nonetheless, after studying some examples of the film analyses carried out with the worksheets provided by these institutions, regardless of the denomination of these fields, the summaries were far from being authentic, comprehensive document summaries that serve as a substitute to viewing the document in question, and thus would be of little real value to users. The summaries could best be defined as storyline overviews, which are shorter, more general summaries with a more commercial purpose in mind. 
Table 2. Presence of aspects related to film content in the analysis worksheets, and field names

\begin{tabular}{|c|c|c|c|c|c|c|}
\hline Worksheet field & $\begin{array}{c}\text { Spanish Film } \\
\text { Library }\end{array}$ & $\begin{array}{c}\text { Andalusian Film } \\
\text { Library }\end{array}$ & $\begin{array}{c}\text { Catalan Film } \\
\text { Library }\end{array}$ & $\begin{array}{c}\text { Valencia Film } \\
\text { Library }\end{array}$ & $\begin{array}{l}\text { Basque Film } \\
\text { Library }\end{array}$ & $\begin{array}{c}\text { Galician Film } \\
\text { Library }\end{array}$ \\
\hline Sumary & $\begin{array}{c}\mathrm{x} \\
\text { (synopsis) }\end{array}$ & $\begin{array}{c}\mathrm{x} \\
\text { (summary) }\end{array}$ & $\begin{array}{c}\mathrm{x} \\
\text { (synopsis) }\end{array}$ & $\begin{array}{c}\mathrm{x} \\
\text { (synopsis and } \\
\text { summary) }\end{array}$ & $\begin{array}{c}\mathrm{x} \\
\text { (synopsis) }\end{array}$ & $\begin{array}{c}\mathrm{x} \\
\text { (storyline) }\end{array}$ \\
\hline Thematic indexing & $\begin{array}{c}\mathrm{x} \\
\text { (subject) }\end{array}$ & $\begin{array}{c}\mathrm{x} \\
\text { (topics/subjects) }\end{array}$ & $\begin{array}{c}x \\
\text { (issue/subject) }\end{array}$ & $\begin{array}{c}\mathrm{x} \\
\text { (keywords) }\end{array}$ & $\begin{array}{c}\mathrm{x} \\
\text { (subject) }\end{array}$ & $\begin{array}{c}\mathrm{x} \\
\text { (descriptors) }\end{array}$ \\
\hline $\begin{array}{l}\text { Onomastic } \\
\text { indexing }\end{array}$ & & & $\begin{array}{c}\mathrm{x} \\
\text { (person/entity) }\end{array}$ & $\begin{array}{c}\mathrm{x} \\
\text { (characters, } \\
\text { interviewer, } \\
\text { interviewee, and } \\
\text { moderator) }\end{array}$ & & \\
\hline \multicolumn{7}{|l|}{$\begin{array}{l}\text { Chronological } \\
\text { indexing }\end{array}$} \\
\hline $\begin{array}{l}\text { Geographical } \\
\text { indexing }\end{array}$ & & & $\begin{array}{c}\mathrm{x} \\
\text { (location) }\end{array}$ & $\begin{array}{c}\mathrm{x} \\
\text { (visual locations } \\
\text { and monuments, } \\
\text { buildings, and } \\
\text { public works) }\end{array}$ & & \\
\hline
\end{tabular}

As to the second major analytic task, that of indexing or representing content in the form of descriptors or keywords, except in the case of the Catalan Film Library, the analysis worksheets do not include a specific field for all of the keywords of the content resulting from this indexing. Therefore, key concepts for searching for and retrieving information in fields with different names in each archive were found to be distributed in the rest of the worksheets.

Moreover, and in the light of the data shown in table 2, we can conclude that, though under different names, this issue is the most important aspect of the film content analyses performed by the film libraries under study in the task of indexing, insofar as all the analysis worksheets include a field for subjects, issues, or topics that represent the film content (regardless of the thoroughness with which they are covered). However, the rest of the index categories (onomastic, geographical, and chronological) are omitted by some of the film libraries in their analysis worksheets, as can be seen in the same table. As a particular subject-related feature, it is worth indicating that the worksheet of the Andalusian Film Library contains the field "Unesco disciplines" for noting the areas of knowledge related to film content, in accordance with the classification drawn up by the Unesco (State Secretariat for Research, Development and Innovation), in addition to one for recording film subjects.

In regards to the onomastic descriptors, it is remarkable that only two of the analysis worksheets, those of the
Catalan and Valencia Film Libraries, include specific fields for recording the people represented in film content. Nonetheless, while in the former case both people and entities are included in this field, in the latter only characters are recorded, although it also contains other specific fields in the "content analysis area", such as "performers", "speaker", "narrator", "voices of", "interviewer", "interviewee", and "moderator", all of which are people-related categories that do not appear in the analysis worksheets of the other film libraries (the first three categories, more truly related to formal analysis than to that of content, and the last three, indeed associated with film content, respectively).

It is obvious that the users of moving image archives cannot at present access the majority of the Spanish film libraries under study to search for and retrieve shots, scenes, sequences, or even whole films in which a specific character is represented. 
On the other hand, on the subject of temporal or chronological descriptors, the absence of a field for the time represented in film documents is also noteworthy because in all seven worksheets analyzed here, only the year when the film was produced, and, only occasionally, the time represented, is indicated in the "synopsis" or "summary" field. Under these circumstances something as simple as searching for and retrieving film-related information based on the time represented in films strikes us as problematic.

\section{The Spanish film libraries do not apply systematically content analysis methodologies that would allow se- lective recovery of audiovisual infor- mation}

Lastly, moving on to the geographical descriptors, only two film libraries -those of Catalonia and Valencia- included them in their analysis worksheets. A special feature in this respect is that the Valencia Film Library incorporates a specific field called "buildings, monuments, and public works" in the "content analysis area" of its worksheet, which is not included in those of the other film libraries, in addition to the "visual locations" and "non-visual film locations" (though this would be associated with formal, rather than content, analysis). The worksheets of the other four film libraries (Spain, Andalusia, the Basque Country, and Galicia) merely contain a field called "locations" for film locations (which could be of the non-visual kind), but not for the places represented or visualized in films.

In general, it should also be underscored that, in regards to indexing, the Valencia Film Library is the only one that incorporates a specific area, "area of content analysis", in its worksheet, which allows us to glimpse a certain degree of concern for film content in the analyses.

Furthermore, none of the film libraries draws a distinction between visual and reference descriptors in their worksheets, as recommended by Caldera-Serrano \& SánchezJiménez (2009, p. 296) when adequately analyzing moving images to separate what is visualized in an image from what is alluded to in the soundtrack. Therefore, in such circumstances users who visit a film library cannot know for sure, before viewing a film or film clip, if the key concept related to its content, on the strength of which the search for and retrieval of information has been performed, is visually present in the image or if it is only hinted at in the soundtrack.

In short, the comparative analysis that we conducted between the fields related to film content in the various document analysis worksheets completed by each film library identified evident shortcomings, as well as differences and a lack of homogeneity in their film content analyses.

\subsection{Film content analysis as envisaged by the libra- rians working at Spanish film libraries}

With regard to our second methodological line of research (that of establishing personal contact by means of interviews), it is worth noting that the question put to those responsible for the film collections at the six film libraries under study, about whether or not film content analysis methodologies were applied, the answer was unanimous: beyond the formal analysis or cataloging of film documents, film content analyses are indeed performed at all of them.

However, differences were observed in the replies to the question of whether or not content analysis methodologies were applied to film collections employing a minimum unit of analysis smaller than a film (such as a shot, scene, sequence, or news item in the case of newscasts). Even though none of the six film libraries systematically performed this type of comprehensive analysis on its film collections, the Spanish, Catalan, Valencian, and Galician Film Libraries claim that they do indeed perform a sequential or scene content analysis covering the whole film, although only in the case of specific films or film collections (selected according to diverse criteria, particularly geographical proximity). And only three of them declared that they also conduct a shot by shot content analysis of very specific, preselected whole films (as is the case of the Catalan, Valencian, and Galician Film Libraries). Nonetheless, except in the case of the Spanish and Catalan Film Libraries, and only for sequential or scene analysis, they were unable to provide us with any example of these highly comprehensive analyses, all of which suggests that the very notion of specific content analysis (be it sequential, scene, or shot by shot) does not seem to be very clear in the minds of their librarians.

\section{The six film libraries analyzed made sub- ject indexing, but the onomastic, geo- graphical and chronological indexing are omitted by some of them}

While bearing in mind these results, if we take a look at some of the film records of these specific collections, as is the case of the No-Do Collection of the Spanish Film Library, we can observe (see Image 2) that the comprehensiveness and systemization of the said analyses have certain shortcomings. In the specific case of this collection, film content analysis is limited to a chronological description (set out in a brief sentence and without numbering the respective clips of the film footage making up each one of the No-Do newscasts), without extracting key concepts of indexing or indicating the time codes that would help users to quickly locate the film clips of interest to them (in the film as a whole).

On the other hand, in the specific case of the Basque Film Library, on which we will now dwell briefly, it should be noted that although they do not generally and systematically perform analysis on units smaller than a film, they conduct a document analysis (as has already been mentioned) that 


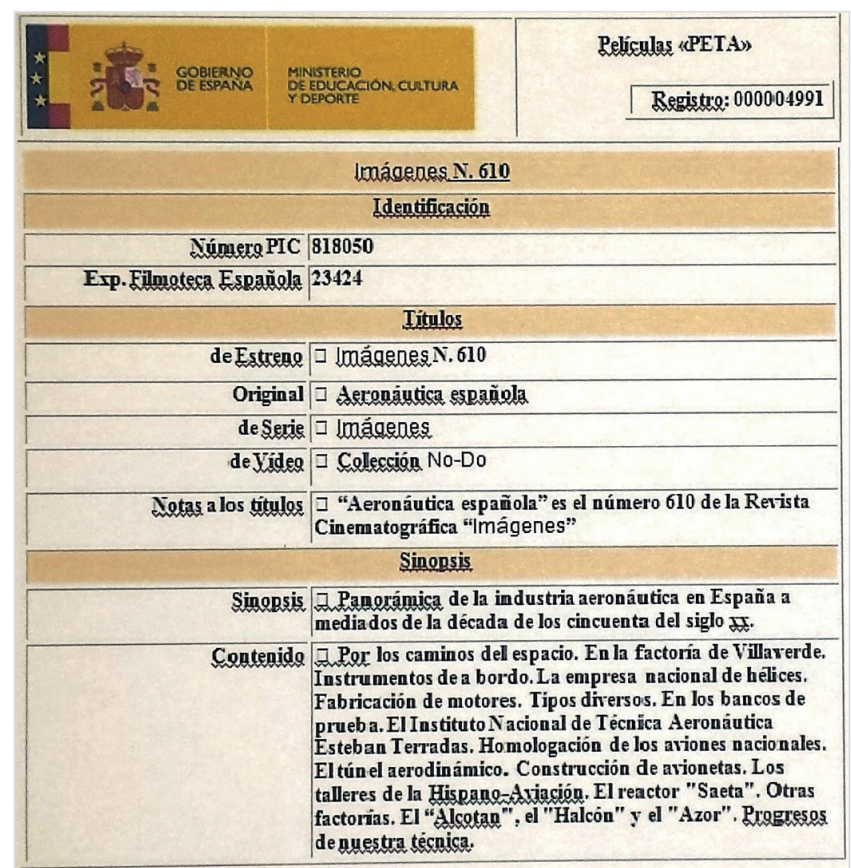

Image 2. Extract of the document analysis worksheet of No-Do (the Spanish Film Library).

focuses on the content of particular film clips, specifically selected in accordance with thematic and geographical criteria, though only in the case of films that have been individually chosen following the same criteria, as can be observed in Image 3.

In the database of this film library, a start and end time code, duration, an attributed descriptive title of the content, a representative keyframe, and, only in some cases, a description of its content between one and three lines long is assigned to each film clip. Likewise, in the "synopsis" field of the analysis worksheets of family video-type films, some of whose clips have been the object of analysis, a content list is drawn up (summarized in a one-line description that, in many cases, coincides with the title attributed to each unit of analysis) only for the selected clips, without offering an overview of the video in which they appear and without including the content of the clips that have not been selected in this synopsis.

Despite its innovative character (versus the analytic methods used by the other film libraries under study, which pay scant attention to the content of specific film clips), the system employed by the Basque Film Library is not without its drawbacks:

- On the one hand, those video clips that have not been selected for analysis (and which could be very helpful for many users) are omitted;
- On the other, only whole videos are indexed (thus making it impossible to retrieve information from these clips).

Nonetheless, this film library has informed us that the information contained in the records of these films is being continually updated as more data on them is obtained or on the basis of the requests made by the users themselves.

Lastly, the Basque Film Library's counterpart, the Andalusian Film Library, is the one and only institution that analyzes film content by items (considering a film as a minimum unit of analysis), without ever describing the content of a specifically selected sequence, scene, shot, news item, or clip in the film content analysis.

\section{Half of the film libraries interviewed (those of the Basque Country, Galicia, and Valencia) do not have a thesaurus with terms related to the content of film documents}

Given that this type of analytical methodology is not applied across the board, we asked the film libraries that do not systematically apply it to whole films (even though they are only specific films or collections) whether they had considered doing so. In response to our question, the Andalusian Film Library claimed that it had considered the possibility, whereas the Basque Film Library, which does indeed perform this type of analysis, but only on specific clips, had not considered it.

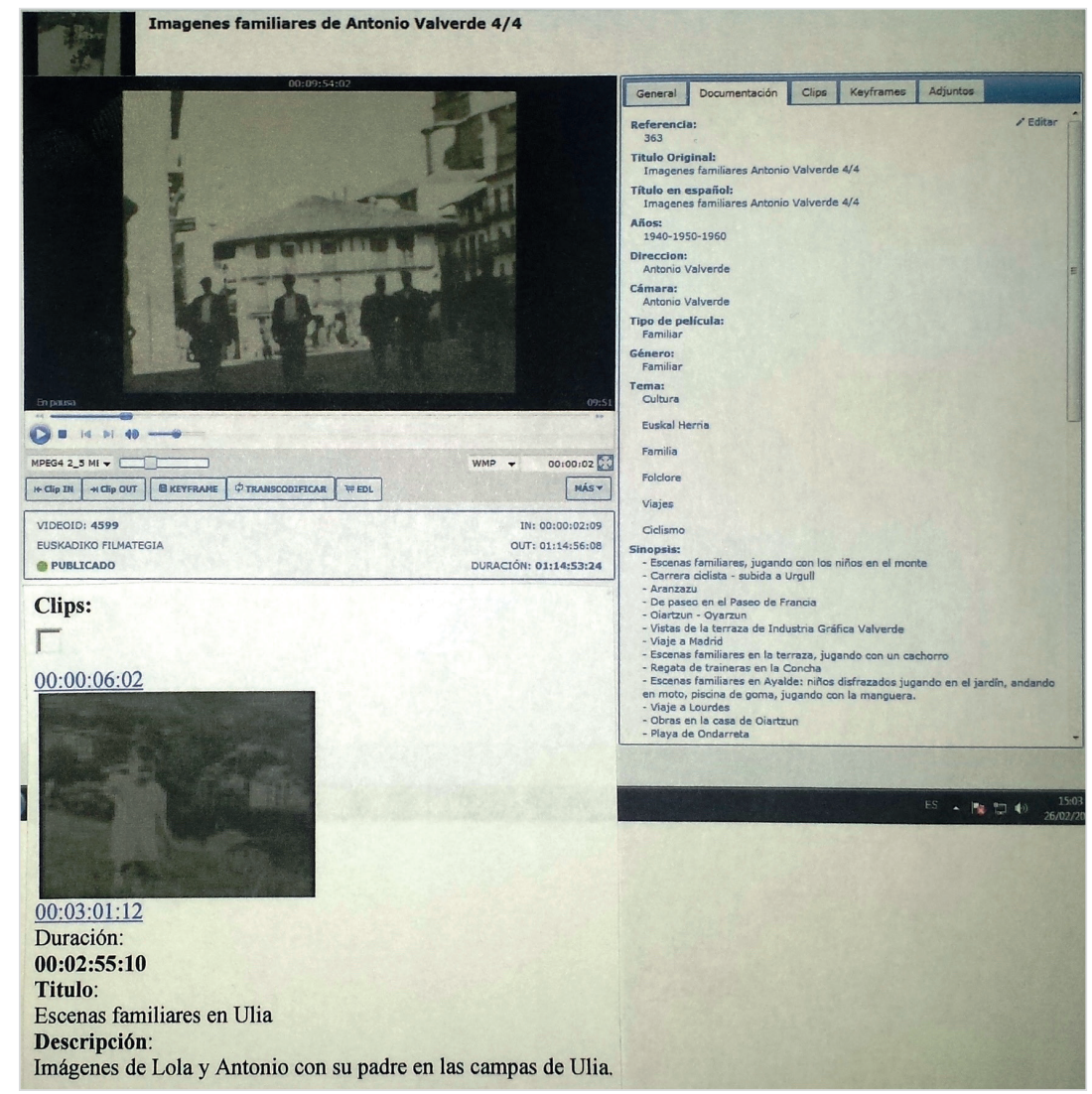

Image 3. Extract of the most comprehensive document analysis worksheet of the Basque Film Library. 
We also asked the information specialists of the six film libraries under study whether they believed that the application of a scientifically validated method for performing this type of specific film content analysis on their film collections would be interesting and helpful for their users, on the one hand, and feasible, on the other. In response, all of the film libraries believed that such an application would be in the interest of their users. As to the second point, only two of the six film libraries thought that this would be impractical, indicating a lack of financial, human, and technical resources as the fundamental reason.

\section{If film content is not systematically analy- zed, the film-related information search and retrieval options open to users will be limited to formal or external fields}

Moreover, we believe that it would be convenient to identify the profile of users who visit the six film libraries under study. According to the information that the libraries provided us, users are basically as follows, in descending order of the frequency of visits:

- researchers (a profile indicated by five of the six film libraries);

- students (indicated by four);

- producers (indicated by half of them);

- museums and television companies (indicated by two in each case);

- audiovisual professionals, documentalists, and historians (indicated by only one in each case).

And in regards the most frequent requests from these users, they usually involve documentaries (indicated by five of the six film libraries under study), although, to a lesser extent and in descending order of the number of requests: family films (indicated by two), fiction films related to a specific geographical scope, experimental films, and amateur films (indicated by only one in each case).

Besides the profiles of the users and the collections most frequently requested, the most common response to the question of how users search for film-related information was by date or year (indicated by four of the six film libraries), followed by the title, director, producer or production company, and performer (indicated by three in each case). In this regard, it would seem reasonable that if film content is not systematically analyzed, the film-related information search and retrieval options open to users will be limited to these formal or external fields. However, other less habitual forms of search are by location (indicated by two) and by gender, subject, thematic area, and collection (indicated by only one in each case).

Still on the subject of information search and retrieval, when asked if they used a thesaurus to standardize indexing and information search terms, only four of the six film libraries under study (those of Catalonia, Andalusia, Spain, and Valencia) provide this important tool, although only the last library mentioned incorporates terms related to technical fields in its thesaurus, though not content-related ones. Therefore, half of the film libraries interviewed (those of the
Basque Country, Galicia, and Valencia) do not have a thesaurus with terms related to the content of film documents, which entails a number of disadvantages (those associated with problems such as synonymy and polysemy, above all) for users when searching for and retrieving information.

\section{Conclusions}

While it is true that, over the last few decades, considerable advances have been made in vindicating the documentary value of films or in the conservationist aspects of moving image archives (Borde, 1991), the same cannot be said of the methodological terrain of film content analysis. As has been shown in this study, current analysis has alarming shortcomings and is characterized by an evident heterogeneity of criteria and models and by the absence of a systematic and general application of specific content analysis methodologies that allow for the selective retrieval of moving images.

\section{The current analysis has alarming shortcomings and is characterized by an evident heterogeneity of criteria and models}

We attribute this to the lack of concern for the content by both the professionals working at film libraries and the FIAF and in the theoretical realm of film librarianship, whose researchers have scarcely experimented with methodologies of this type in Spain. We should not overlook the insufficient recognition and government financial support for Spanish film archives, resulting in a lack of personnel and resources which hinders the development of innovative projects that facilitate access to film content.

But we understand that, in the technological and digital age, it is right and proper that the users of film archives enjoy the same privileges as granted to those of TV archives when selectively searching for and retrieving film-related information at film libraries, with the satisfaction and enormous savings in time and effort that this would entail, an essential issue in a world dominated by information saturation and new technologies. On the contrary, there is a danger that the difficulties in locating film content will deter users from visiting film libraries, which would also jeopardize the interest of citizens and researchers in this valuable documentary heritage.

For all the above reasons, we call for the opening of new research approaches and constant dialogue between researchers, information specialists working at film libraries, and users of moving image archives in order to make the Spanish film heritage more accessible to citizens and foster the use of these resources in research.

\section{Notes}

1. We are deeply indebted to the Spanish, Andalusian, CataIan, Basque, Valencia, and Galician Film Libraries for their vital contribution to this study by making their film content analysis worksheets available to us and offering to participate in the interviews and complete the questionnaires. 
2. Noticiarios y Documentales [Newsreels and Documentaries], the main propaganda medium of Francoism in Spain, created by order of the Vicesecretaría de Educación Popular [Vice-secretary of Popular Education], dated 17 December 1942. From 1943 to 1981 they were screened in Spanish cinemas (obligatorily until 1976).

\section{References}

Agirreazaldegi-Berriozabal, Teresa (2007). "Claves y retos de la documentación digital en televisión". El profesional de la información, v. 16, n. 5, pp. 433-442.

https://doi.org/10.3145/epi.2007.sep.05

Borde, Raymond (1991). Los archivos cinematográficos. Valencia: Filmoteca de la Generalitat Valenciana. ISBN: $847890302 \mathrm{X}$

Caldera-Serrano, Jorge; Sánchez-Jiménez, Rodrigo (2009). "Recuperación de secuencias de información audiovisual con rdf y smil". El profesional de la información, v. 18, n. 3, pp. 291-299.

https://doi.org/10.3145/epi.2009.may.06

FIAF (Federación Internacional de Archivos Fílmicos) (1998). Reglas de catalogación de la FIAF para archivos fílmicos. México D.F.: Archivo General de Puerto Rico y Filmoteca de la UNAM. ISBN: 9683667414

Fox, Virginia (2005). Análisis documental de contenido. Principios y prácticas. Ciudad Autónoma de Buenos Aires: Alfagrama Ediciones. ISBN: 9872207402

López-Hernández, Ángeles (2003). Introducción a la do- cumentación audiovisual. Carmona: S\&C Ediciones. ISBN: $849239157 X$

Unesco (Organización de las Naciones Unidas para la Educación, la Ciencia y la Cultura) (1980). "Recomendaciones para la salvaguardia y conservación de imágenes en movimiento". En: Actas de la conferencia general. 21a Reunión, 23 de septiembre - 28 de octubre de 1980. Volumen 1. Resoluciones. París: Unesco, pp. 167-172.

http://unesdoc.unesco.org/images/0011/001140/114029s. $p d f$

Pinto-Molina, María (1992). El resumen documental. Principios y métodos. Madrid: Fundación Germán Sánchez Ruipérez y Ediciones Pirámide. ISBN: 8486168708

Pinto-Molina, María; García-Marco, Francisco-Javier; Agustín-Lacruz, María-del-Carmen (2002). Indización y resumen de documentos digitales y multimedia. Técnicas y procedimientos. Gijón: Ediciones Trea. ISBN: 8497040236

Rodríguez-Mateos, David; Pérez-Lorenzo, Belén (2011). "Análisis documental de contenidos audiovisuales". En: Caridad-Sebastián, Mercedes; Hernández-Pérez, Tony; Rodríguez-Mateos, David; Pérez-Lorenzo, Belén. Documentación audiovisual. Nuevas tendencias en el entorno digital. Madrid: Síntesis, pp. 111-134. ISBN: 9788497567466

Secretaría de Estado de Investigación, Desarrollo e Innovación (Ministerio de Economía y Competitividad, Gobierno de España). Nomenclatura internacional de la Unesco para los campos de ciencia y tecnología.

http://goo.gl/ntNV6A

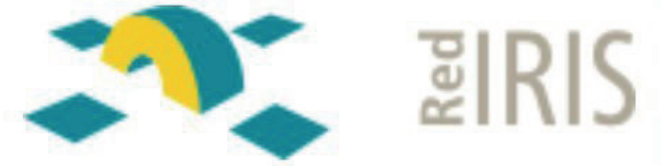

https://www.rediris.es/list/info/iwetel.html

\section{IWETEL \\ Foro para profesionales de bibliotecas y documentación}

Con unos 6.000 miembros, IweTel es la mayor lista de distribución en castellano para debatir y estar al día sobre temas de biblioteconomía y documentación.

Fue creada en 1993 por Tomàs Baiget, como complemento de Information World en Español (IWE), revista que en 1999 pasó a denominarse El profesional de la información (EP/).

Desde 1998 IweTel está alojada en el servicio de listas de RedIRIS, siendo posible consultar en sus archivos estos 18 años de la historia de la documentación en España:

https://listserv.rediris.es/cgi-bin/wa?A0=IWETEL

La lista cuenta con 4 moderadores que permanentemente filtran los mensajes para evitar spam, mensajes inapropiados, anuncios, mensajes repetidos, etc.:

David Gómez (Observatorio de la Infancia de Andalucía),

Isabel Olea (EPI, León),

Nieves González-Fernández-Villavicencio (Universidad Pablo de Olavide, Sevilla),

Tomàs Baiget (EPI, Barcelona).

Puedes suscribirte a IweTel en:

https://listserv.rediris.es/cgi-bin/wa?SUBED1=/WETEL\&A=1 